\title{
Pengembangan Multimedia Berbasis Etnomatematika Pada Materi Bangun Datar Kelas IV Sekolah Dasar
}

\author{
Dewi Yuli Setyoningrum*, Supriyono, Rintis Rizkia Pangestika \\ Universitas Muhammadiyah Purworejo, Indonesia \\ *Coresponding Author: dewiyulisetyoningrum@gmail.com
}

Article History

Received 2021-08-21

Revised 2021-11-29

Accepted 2022-01-17

DOI:

10.31949/educatio.v8i1.1419

\begin{abstract}
Learning mathematics will be meaningful if it is associated with real-life problems. Ethnomathematics is an activity in which there are mathematical concepts associated with local culture and students often encounter them in real life. Ethnomathematics needs to be implemented in students starting at the elementary school level, it aims to make it easier for students to understand mathematical concepts. This study aims to 1) Develop ethnomathematics-based multimedia in the fourth grade elementary school flat-building material. (2) determine the feasibility of ethnomathematical-based multimedia in the fourth grade elementary school flat-building material. The implementation in this research uses the ADDIE development model (Analysis, Design, Development, Implementation and Evaluation). Research results on the development of ethnomathematical-based multimedia: 1) the product developed produces learning media in the form of ethnomathematical-based multimedia that can be used as a reference source and media for learning. 2) the results of the validation carried out by media experts, material experts, and education practitioners on the developed multimedia obtained an average total score of 3.68 with very valid criteria, then student responses obtained an average score with very practical criteria, and completeness evaluation tests on students who reach $88 \%$ so that the use of multimedia is considered effective.
\end{abstract}

Keywords: ethnomathematics; multimedia; mathematics learning

\section{PENDAHULUAN}

Matematika adalah mata pelajaran yang diberikan pada semua jenjang pendidikan, untuk membekali peserta didik dalam berpikir kritis, logis, sistematis dan kreatif. Matematika sangat penting dalam bidang pendidikan dan bidang teknologi. Matematika merupakan ilmu yang memiliki sifat abstrak (Baker, 2009; 
Widodo, 2018), sehingga menjadikan siswa sulit dalam memahami materi. Sifat keabstrakan itu dapat dibantu dengan media pembelajaran atau alat peraga, penggunaan benda-benda konkret dan lainnya dapat memudahkan peserta didik dalam memahami matematika. Pembelajaran matematika hendaknya dikaitkan dengan permasalahan pada kehidupan nyata (Mazana et al, 2019; Sevinc \& Lesh, 2018). Jika dalam belajar matematika tidak dikaitkan dengan kehidupan nyata atau pengalaman-pengalaman yang dialami, peserta didik akan cepat mudah lupa. Mustamin (2017) mengemukakan bahwa proses pembelajaran matematika yang dilakukan di dalam kelas dibutuhkan adanya penekanan pada hubungan konsep matematika dengan pengalaman peserta didik sehari-hari. Selain itu, juga dibutuhkan adanya penerapan kembali konsep matematika yang sudah dimiliki peserta didik dalam kehidupan sehari-hari. Diantari et al. (2019) berpendapat bahwa pendidikan jenjang sekolah dasar dalam pembelajaran matematika perlu memperhatikan sifat dasar peserta didik yang mulai berpikir secara logis serta menggunakan benda konkret untuk memahami konsep yang bersifat abstrak. Maka dari itu, agar mempermudah peserta didik dalam memahami matematika dapat menggunakan alat peraga, benda-benda konkret, menggunakan teknologi informasi dan komunikasi seperti komputer dan media pembelajaran matematika lainnya.

Perkembangan teknologi yang semakin canggih ini membuat adanya pergeseran dari yang konvensional ke modern. Pembelajaran konvensional merupakan pembelajaran yang dilakukan oleh guru dalam menyampaikan materi dengan metode ceramah, dalam pembelajaran hanya menggunakan buku paket dan kurang banyak menggunaan alat dan bahan praktik. . Dalam pembelajaran matematika, banyak siswa yang kurang memahami perkalian dan pembagian serta belum adanya buku penunjang yang terfokus dalam satu materi, hanya terdapat buku teks dari pemerintah yang membahas materi secara umum dan siswa hanya menghafal materi tanpa ada kreasi yang memudahkan siswa untuk memahami materi. Pembelajaran konvensional tersebut membuat peserta didik hanya menghafal konsep-konsep yang diberikan oleh guru sehingga minat belajar peserta didik berkurang serta kurang maksimalnya potensi peserta didik. Tetapi kenyataan yang terdapat di lapangan, semua guru belum bisa menyusun perangkat pendidikan dengan baik (Nusaibah \& Murdiyani, 2017). Seiring dengan perkembangan zaman yang semakin modern diharapkan pendidik mampu memanfaatkan teknologi tersebut sebagai pembuatan media pembelajaran untuk mengoptimalkan proses pembelajarannya. Menurut Nurdyansyah (2019) pemakaian media pembelajaran dapat meningkatkan motivasi, keaktifan dan minat baru peserta didik, dan dapat meningkatkan rangsangan kegiatan dalam proses belajarnya. Nurdyansyah (2019) menyatakan bahwa kegiatan pembelajaran berbantuan visual yang berupa alat peraga atau media pembelajaran dapat memberikan pengalaman visual kepada peserta didik, mendorong motivasi belajar, memperjelas dan memudahkan konsep abstrak yang bersifat kompleks menjadi lebih sederhana, spesifik dan mudah dipahami. Media pembelajaran yang memanfaatkan teknologi ada berbagai macam seperti Power Point, Audiovisual, Video, Game dan lain sebagainya.

Perkembangan media saat ini tidak hanya mengutamakan penampilan saja, tetapi dalam pengaplikasiannya sudah menggunakan penggabungan dari semua media yang kita sebut "multimedia". Multimedia merupakan media pembelajaran yang menggabungkan dua unsur atau lebih yang terdiri dari video, suara, gambar, grafik, teks, animasi dan lainnya secara menarik. Multimedia juga bisa memberikan pengalaman belajar yang menarik dan bermakna untuk peserta didik. Hal tersebut sesuai dengan tahap berpikir peserta didik yang masih terkait dengan hal-hal atau benda-benda yang konkret. Pembuatan multimedia yang menggunakan teknologi ternyata tidak hanya terdapat dampak positif saja, melainkan juga terdapat dampak negatifnya. Teknologi informasi yang kini semakin canggih, membuat bangsa Indonesia semakin krisis jati diri. Terutama para pelajar, mereka kini berlomba-lomba dalam perkembangan zaman. Perkembangan teknologi yang begitu pesat membuat mereka buta akan dunia maya, dan tidak melihat apa yang ada disekitar. Budaya asing yang kini semakin banyak digemari para pelajar, karena budaya asing yang dikemas dengan baik dan selalu mengikuti perkembangan zaman.

Perkembangan zaman yang kini semakin pesat membuat peserta didik semakin krisis akan budaya yang ada di Indonesia. Pengikisan tersebut terjadi karena peserta didik lebih senang menggunakan gadget yang digunakan untuk mengakses budaya-budaya asing. Perlu adanya sikap menghargai dan melestarikan budaya asli Indonesia, agar tidak terjadi pengikisan budaya pada bangsa kita sendiri dan juga pembentukan karakter 
yang didasarkan pada nilai budaya. Cara yang digunakan agar tidak terjadi pengikisan pada generasi milenial dan juga untuk mencapai tujuan pembelajaran ini, nilai-nilai budaya perlu diintegrasikan ke dalam pembelajaran matematika yaitu melalui pendekatan etnomatematika atau pembelajaran berbasis etnomatematika. Etnomatematika merupakan salah satu wujud pendekatan pembelajaran yang menghubungkan budaya lokal dengan pembelajaran matematika (Achor et al, 2009; Nadhilah et al, 2020). Kebudayaan dengan matematika memiliki hubungan yang erat (Gosztonyi, 2016; Knijnik, 2007), karena pada kehidupan sehari-hari mereka selalu dibutuhkan. Diharapkan dengan adanya Etnomatematika ini mampu membuat peserta didik belajar mengenai konsep matematika beserta penanaman karakter. Pembelajaran yang berbasis etnomatematika dengan mengkaitkan kearifan budaya lokal dalam pembelajaran matematika, dapat membantu peserta didik dalam memahami konsep matematika secara kontekstual dan memahami keberagaman budaya yang ada disekitar peserta didik yang kemudian dikaitkan dengan matematika. Melalui pembelajaran etnomatematika guru dapat menanamkan nilai-nilai luhur budaya dan 5 memiliki dampak pada pendidikan karakter. Produk budaya yang akan diterapkan dalam multimedia ini adalah rumah adat pada materi bangun datar.

Berdasarkan hasil wawancara dengan guru kelas IV SD Negeri Ayamalas 03 diketahui bahwa dalam melaksanakan proses pembelajaran guru masih menggunakan metode pembelajaran ceramah, karena metode tersebut tidak susah dalam pelaksanaannya. Sumber belajar yang digunakan dalam pembelajaran di SD Negeri Ayamalas 03 yaitu menggunakan buku yang dari pemerintah. Penggunaan buku dari pemerintah sebagai sumber belajar peserta didik tidak menarik dan kurang antusias dalam pembelajaran. Maka dari itu guru juga menggunakan YouTube dan video pembelajaran sebagai tambahan sumber belajar dan media pembelajaran. Tetapi, untuk pembelajaran matematika sendiri, peserta didik kurang tertarik atau merasa takut dengan matematika. Dikarenakan mereka belum paham mengenai konsep matematika tersebut. Media pembelajaran sebagai penunjang pembelajaran matematika di SD Negeri Ayamalas 03 juga belum ada. Media pembelajaran yang digunakan dalam mata pelajaran matematika masih bersifat abstrak. Berdasarkan permasalahan di atas, penulis tertarik untuk mengembangkan media pembelajaran matematika berbasis Etnomatematika untuk memenuhi kebutuhan peserta didik dalam memahami konsep matematika. Media pembelajaran yang dimaksud adalah Multimedia. Multimedia tersebut juga dapat mengatasi kesulitan peserta didik dalam matematika, meningkatkan minat belajar peserta didik dan pemanfaatan teknologi pembelajaran. Pengembangan media pembelajaran ini diperlukan 6 suatu model perngembangan. Terdapat beberapa model pengembangan yang sudah banyak digunakan saat ini. Salah satunya yaitu model pengembangan ADDIE. Multimedia ini nanti diharapkan dapat berguna sebagai media pembelajaran bagi siswa dalam memahami materi dan memudahkan pendidik dalam menyampaikan materi.

\section{METODE PENELITIAN}

Model penelitian yang digunakan merupakan metode penelitian dan pengembangan atau yang biasa disebut Research and Development (R\&D). Metode penelitian dan pengembangan atau Research and Development (R\&D) merupakan sebuah metode yang digunakan untuk menghasilkan dan menguji kefektifan sebuah produk tertentu. Produk yang dikembangakan dalam penelitian ini adalah multimedia berbasis etnomatematika materi bangun datar kelas IV sekolah dasar. Pengembangan multimedia berbasis etnomatematika ini menggunakan model pengembangan ADDIE. Model pengembangan ADDIE yang dikembangkan oleh Dick and Carry pada tahun 1996 terdiri atas 5 tahapan yakni 1) Analysis (analisis), 2) Design (perancangan), 3) Development (pengembangan), 4) Implementation (implementasi), 5) Evaluation (evaluasi).

Penelitian ini dilaksanakan di SD Negeri Ayamalas 03, Kecamatan Kroya, Kabupaten Cilacap. Subjek dalam penelitian pengembangan multimedia berbasis etnomatematika yaitu peserta didik kelas IV SD Negeri Ayamalas 03. Sedangkan objek dalam penelitian pengembangan ini adalah multimedia berbasis etnomatematika pada peserta didik kelas IV SD Negeri Ayamalas 03.

Prosedur pengumpulan data dalam penelitian ini dilakukan dengan 3 metode yaitu metode wawancara, metode angket dan metode tes. Pemerolehan data dalam penelitian ini adalah skor hasil dari 
pengisian lembar validasi produk oleh validator yaitu Bapak Suyoto, M. Pd., selaku dosen ahli media, Bapak Prasetyo Budi Darmono, M. Pd., selaku dosen ahli materi, dan Bapak Maryanto, S. Pd., selaku praktisi pendidikan untuk mengetahui kevalidan dari produk yang telah dikembangkan. Pemerolehan skor dari hasil pengisisan angket peserta didik untuk mengetahui kepraktisan dari penggunaan multimedia yang dikembangkan, dan ketuntasan hasil tes peserta didik setelah dilakukannya evaluasi sebagai tolak ukur keefektifan penggunaan multimedia yang dikembangkan.

\section{HASIL DAN PEMBAHASAN}

Pengembangan multimedia berbasis etnomatematika materi bangun datar kelas IV sekolah dasar menggunakan model ADDIE memiliki 5 tahap yaitu analysis, design, development, implementation, dan evaluation.

Tahap analisis dalam penelitian ini meliputi analisis kebutuhan dan analisis materi. Analisis Kebutuhan analisis kebutuhan ini mengarahkan pada situasi atau kondisi sekolah yang akan dijadikan sebagai tempat penelitian yaitu SD Negeri Ayamalas 03. Analisis ini dibutuhkan guna untuk mengetahui kurikulum yang digunakan, sumber dan media pembelajaran yang digunakan, metode pembelajaran yang sudah diterapkan dan apakah multimedia pembelajaran perlu dikembangkan atau tidak. Analisis kebutuhan ini didasarkan pada hasil wawancara yang dilakukan dengan guru kelas IV sebagai berikut: Sumber belajar dan media pembelajaran yang digunakan adalah buku dari pemerintah, video dan PowerPoint (PPT), metode pembelajaran yang digunakan yaitu metode ceramah, kendala dalam pembelajaran matematika yaitu peserta didik kurang paham mengenai konsep matematika dan peserta didik tidak rajin belajar, menggunaan media pembelajaran yang berbasis budaya masih jarang digunakan. Berdasarkan hasil wawancara maka perlu dilakukan pengembangan multimedia berbasis etnomatematika. Sebelum lanjut ke tahap design, maka perlu melakukan analisis materi, agar materi dalam multimedia yang akan dikembangkan memiliki relevansi dan bermanfaat. Pada analisis materi dilakukan dengan cara mengidentifikasi materi utama yang diajarkan, mengumpulkan dan memilih materi yang relevan kemudian disusun kembali secara sistematis. Analisis materi didasarkan pada hasil wawancara terhadap guru kelas IV yaitu materi yang diajarkan untuk kelas IV semester genap ini salah satunya adalah bangun datar dengan menggunakan kurikulum 2013. Hal ini dilakukan agar apa yang dikembangkan dapat bermanfaat untuk peserta didik dan guru. Oleh karena itu, pengumpulan dan pemilihan materi bangun datar ini digunakan sebagai multimedia pembelajaran yang sistematis dengan pokok bahasan bangun datar.

Tahapan perancangan dalam penelitian ini diantaranya yaitu menyiapkan desain awal multimedia pembelajaran atau desain produk. Kegiatan yang dilakukan pada tahan desain ini yaitu penyajian materi dan pembuatan storyboaard. Pada penyajian materi bahan-bahan yang telah didapatkan dari tahapan analisis yang telah dilakukan yaitu pengisian materi peneliti mengacu pada buku matematika dari Kemendikbud edisi revisi tahun 2017, internet untuk mengisi pada etnomatematika tentang rumah adat Jawa Tengah (Joglo) dan Aceh (Rumoh Aceh) dan sumber lain yang berkaitan dengan materi bangun datar, pembuatan multimedia pembelajaran, peneliti juga menggunakan aplikasi Adobe Flash CS6, juga terdapat aplikasi pendukung seperti Pixellab, Microsoft Office Word 2013, Voice Changer, powtoon dan GoldWave. Sedangkan pembuatan storyboard untuk memberikan gambaran yang lebih jelas untuk dilihat dari tata tampilan dan tata letak media pembelajaran.

Tahap development berisikan kegiatan realistis rancangan produk. Pada tahap pengembangan ini, kegiatan yang dilakukan yaitu pembuatan produk, instrumen penilaian dan validasi ahli serta revisi produk. Pembuatan produk dilakukan berdasarkan rancangan desain produk, kemudian dibuat suatu produk rill berupa multimedia berbasis etnomatematika dengan merangkai komponen-komponen yang telah disiapkan dalam pembuatan produk. Seperti aplikasi Adobe Flash CS6, dan berbagai referensi pengisi dari multimedia. Instrumen Penilaian dibuat sebagai sarana untuk mengukur kinerja dari produk yang dikembangkan untuk mengetahui kesesuaian produk dengan materi. Instrumen penilaian terhadap produk yang dikembangkan akan divalidasikan kepada ahli media, ahli materi, dan praktisi pendidikan sebagai salah satu syarat kelayakan dari produk yang dikembangkan. Validasi Ahli, sebelum multimedia berbasis etnomatematika digunakan, multimedia harus melalui tahap validasi oleh validator ahli. Validasi dilakukan oleh Bapak Suyoto, M. Pd. 
Selaku dosen ahli media, Bapak Prasetyo Budi Darmono, M. Pd. selaku dosen ahli materi, dan Bapak Maryanto, S. Pd. selaku praktisi pendidikan. Tahap validasi yang dilakukan adalah dengan mengajukan produk kepada para validator untuk kemudian divalidasi. Kemudian hasil dari validasi tersebut, diberikan berupa komentar, masukan, dam saran yang membangun untuk perbaikan media agar lebih baik lagi. Revisi produk merupakan hasil dari tahap validasi oleh ahli yang digunakan untuk memperbaiki produk agar lebih baik dan menarik perhatian, serta materi yang disesuaikan validasi para ahli sebelum produk di uji cobakan. Hasil validasi yang berupa penilaian, saran, dan kritikan dijadikan sebuah pedoman dalam merevisi produk agar menghasilkan produk media yang layak sebelum di uji cobakan di lapangan.

Pada tahap implementasi, produk yang telah dirancang dan dikembangkan kemudian diimplementasikan didalam proses pembelajaran dikelas, yaitu dengan melakukan uji coba lapangan yang meliputi uji coba lapangan terbatas dan uji coba lapangan secara luas. Multimedia diuji cobakan pada kelompok terbatas sekitar 6 peserta didik dari kelas IV SD Negeri Ayamalas 03 yang dipilih berdasarkan kriteria pemilihan tertentu. Kriteria pemilihan ini dilakukan dengan bantuan guru kelas untuk memilih peserta didik yang memiliki prestasi tinggi, sedang, dan rendah. Pada tahap ini juga dibagikan angeket untuk mengetahui respon peserta didik terhadap penggunaan multimedia berbasis etnomatematika dalam proses pembelajaran. Multimedia yang telah diuji cobakan pada kelompok peserta didik kelas IV sebelumnya, kemudia dilakukan uji coba lapangan luas pada kelompok berikutnya yang terdiri dari 14 peserta didik. Pada tahap ini juga diberikan angket untuk mengetahui respon peserta didik terhadap multimedia yang telah dibuat dan tingkat kepraktisan dari multimedia yang dikembangkan.

Tahap evaluasi dilakukan guna untuk mengetahui keefektifan dari penggunaan multimedia berbasis etnomatematika dalam proses pembelajaran. Namun tidak hanya itu saja, evaluasi juga diberikan kepada peserta didik untuk mengukur kompetensi akhir dari mata pelajaran atau tujuan pembelajaran yang ingin dicapai. Tahap ini dilakukan setelah proses pembelajaran selesai dengan pemberian soal tes atau evaluasi kepada peserta didik untuk mengukur ketercapaian KKM setelah menggunakan multimedia berbasis etnomatematika

Data yang telah terkumpul selanjutnya diolah untuk melihat kevalidan, kepraktisan, dan keefektifan produk.

1. Kevalidan Multimedia Berbasis Etnomatematika

Multimedia dapat dikatakan valid apabila telah dilakukan uji validasi yang dilakukan oleh validator. Data hasil penilaian dari validasi produk pengembangan Multimedia Berbasis Etnomatematika berupa skor aktual yang diberikan oleh ahli media, ahli materi, dan praktisi pendidikan.

Tabel 3. Hasil Validasi Oleh Dosen Ahli dan Praktisi Pendidikan

\begin{tabular}{cccc} 
No & Aspek/Indikator & Rata-rata & Kriteria \\
\hline 1 & Ahli Media & 3,56 & Sangat Valid \\
2 & Ahli Materi & 3,58 & Sangat Valid \\
3 & Praktisi Pendidikan & 3,90 & Sangat Valid \\
& Total Rata-rata & 3,68 & Sangat Valid \\
\hline
\end{tabular}

Kualitas multimedia berdasarkan aspek kevalidan yang didapat dari hasil angket validasi media, materi dan praktisi guru dapat dikatakan memiliki kevalidan yang baik. Jika minimal tingkat kevalidan yang dicapai masuk dalam kriteria valid atau mencapai $>2,50$ dan multimedia pembelajaran berbasis etnomatematika mendapatkan penilaian dari ahli media dengan rata-rata skor sebesar 3,56 dengan kategori sangat valid. Multimedia berbasis etnomatematika juga mendapatkan penilaian dari ahli materi dengan rata-rata skor 3,58 dengan kategori sangat valid dan penilaian dari praktisi guru mendapatkan rata-rata skor 3,90 dengan kategori sangat valid. Berdasarkan validasi yang telah dilakukan oleh ahli media, materi dan praktisi guru bahwa multimedia berbasis etnomatematika pada materi bangun datar kelas IV sekolah dasar mendapatkan rata-rata skor 3,68 dengan kategori sangat valid. 
2. Kepraktisan Multimedia Berbasis Etnomatematika

Kepraktisan multimedia berbasis etnomatematika diukur dari angket respon peserta didik yang diberikan pada saat uji coba lapangan terbatas dan uji coba lapangan luas.

Tabel 4. Hasil Respon Peserta Didik Uji Coba Lapangan

\begin{tabular}{cccc}
\hline No & Uji Coba Lapangan & Rata-rata & Kriteria \\
\hline 1 & Terbatas & 3,42 & Sangat Praktis \\
2 & Luas & 3,44 & Sangat Praktis \\
& Total Rata-rata & 3,43 & Sangat Praktis \\
\hline
\end{tabular}

Jika minimal tingkat kevalidan yang dicapai masuk dalam kriteria valid atau mencapai $>2,50$. Multimedia berbasis etnomatematika mendapatkan penilaian dari angket respon peserta didik dalam uji coba lapangan terbatas dengan rata-rata skor 3,42 dengan kategori sangat praktis dan uji coba lapangan terbatas mendapatkan nilai dengan rata-rata skor 3,44 dengan kategori sangat praktis. Hal tersebut dilihat dari hasil respon peserta didik yang dihitung secara keseluruhan diperoleh rata-rata skor 3,43 dengan kategori sangat praktis.

3. Keefektifan Multimedia Berbasis Etnomatematika

Keefektifan multimedia dinilai dari hasil tes peserta didik yang diberikan setelah pembelajaran dengan menggunakan multimedia berbasis etnomatematika. Keefektifan didapatkan dari analisis hasil tes ketuntasan belajar. Multimedia dapat dikatakan efektif jika 65\% atau lebih peserta didik tuntas belajar. Peserta didik dapat dikatakan tuntas belajar jika memperoleh nilai lebih atau sama dengan kriteria ketuntasan minimum yang ditetapkan yaitu 75. Berdasarkan hasil pemerolehan tes belajar setelah menggunakan multimedia berbasis etnomatematika baik di saat uji coba terbatas dan uji coba luas diperoleh hasil yang maksimal dan sangat baik.

Tabel 5. Hasil Nilai Akhir Peserta Didik Pada Uji Coba Terbatas Dan Uji Coba Luas

\begin{tabular}{lcc}
\hline Uraian & Nilai Akhir & Kriteria \\
\hline Persentase Ketuntatasan Uji Coba Terbatas & $83 \%$ & Efektif \\
Persentase Ketuntasan Uji Coba Luas & $93 \%$ & Efektif \\
Rerata Persentase Ketuntasan & $88 \%$ & Efektif \\
\hline
\end{tabular}

Pada tabel 5. menunjukan bahwa pada uji coba terbatas yang diikuti oleh 6 peserta didik, diperoleh data bahwa 5 peserta didik mendapatkan nilai akhir diatas batas nilai KKM, sehingga dinyatakan tuntas, dan sisanya 1 peserta didik dinyatakan tidak tuntas karena nilai akhirnya masih dibawah nilai KKM. Sehingga pada uji coba terbatas diperoleh persentase ketuntasan sebesar $83 \%$. Sedangkan hasil tes yang diikuti oleh 14 peserta didik pada uji coba luas, dengan data perolehan bahwa nilai akhir dari 13 peserta didik berada diatas batas nilai KKM dan 1 peserta didik dinyatakan tidak tuntas karena nilai akhirnya masih di bawah KKM, sehingga pada uji coba luas persentase ketuntasannya sebesar 93\%. Dimana di uji coba terbatas persentase ketuntasan memperoleh $83 \%$ melebihi $65 \%$ ketentuan dari proses pembelajaran menggunakan multimedia dapat dikatakan efektif, namun masih terdapat satu peserta didik yang nilainya masih dibawah kriteria ketuntasan minimum. Sedangkan diuji coba luas, tingkat ketuntasannya mencapai 93\% melebihi 65\% ketentuan dari proses pembelajaran menggunakan multimedia dapat dikatakan efektif, namun masih terdapat satu peserta didik yang nilainya masih dibawah kriteria ketuntasan minimum. Sehingga perolehan persentase kentuntasan secara keseluruhan yakni $88 \%$.

Illahi et al. (2018) berpendapat multimedia dikatakan efektif dilihat dari hasil belajar. Hal ini sependapat dengan Dwiqi et al. (2020) menyatakan bahwa kemudahan penggunaan, tampilan yang menarik dan kejelasan dalam penyajian materi dapat meningkatkan motivasi belajar peserta didik sehingga berdampak positif terhadap hasil belajar. Menurut Wahyugi \& Fatmariza (2021) menyatakan multimedia dinyatakan efektif dalam meningkatkan motivasi belajar peserta didik, karena multimedia yang dikembangkan memerhatikan aspek perkembangan peserta didik. Sehingga peserta didik tertarik dalam menggunakan 
multimedia dan meningkatkan motivasi belajarnya. Multimedia dinyatakan efektif karena adanya interaksi antara multimedia dan peserta didik (Nugroho \& Surjono, 2019). Hal ini selaras dengan Diyana et al. (2020) keterkaitan interaksi antara multimedia dengan peserta didik terbangun baik juga memperhatikan kognitif peserta didik, maka multimedia dikatakan efektif.

Berdasarkan uraian tersebut, dapat disimpulkan bahwa multimedia yang dikembangkan sangat efektif, sehingga apabila diterapkan dalam kegiatan pembelajaran, karena dapat memudahkan dalam memahami materi, dan memotivasi belajar peserta didik yang mengakibatkan pemerolehan hasil belajar lebih maksimal.

\section{KESIMPULAN}

Pengembangan dari multimedia berbasis etnomatematika menggunakan model ADDIE telah berhasil dikembangkan. Kelayakan dari multimedia berbasis etnomatematika dilihat berdasarkan hasil validasi yang dilakukan oleh ahli media, ahli materi, dan praktisi pendidikan terhadap produk yang dikembangkan mendapatkan total skor rata-rata 3,68 dengan kriteria sangat valid, kemudian respon peserta didik dengan total skor rata-rata 3,43 dengan kriteria sangat praktis, dan ketuntasan tes evaluasi pada peserta didik yang mencapai $88 \%$ dimana menunjukan bahwa penggunaan multimedia berbasis etnomatematika didalam proses pembelajaran dinilai efektif. Sehingga Multimedia Berbasis Etnomatematika Materi Kelas IV Sekolah Dasar yang dikembangkan layak digunakan karena memenuhi kriteria kelayakan yang meliputi valid, praktis, dan efektif.

\section{DAFTAR PUSTAKA}

Achor, E. E., Imoko, B., \& Uloko, E. (2009). Effect of ethnomathematics teaching approach on senior secondary students' achievement and retention in locus. Educational research and review, 4(8), 385-390.

Baharudin, Halimah, A., Nursalam, \& Mattoliang, L. A. (2020). Pengembangan Media Pembelajaran Interaktif Berbasis Multimedia. Journal of Islamic Education, 2(1), 97-110.

Baker, A. (2009). Mathematical Explanation in Science. The British Journal for the Philosophy of Science, 611-633.

Diantari, N. L. G. A., Gading, I. K., \& Japa, I. G. N. (2019). Pengaruh Model Pembelajaran Missouri Mathematics Project Realistik Berbantuan LKS Terhadap Hasil Belajar Matematika. Jurnal Ilmiah Pendidikan Dan Pembelajaran, 3(2), 127-136.

Diyana, T. N., Supriana, E., \& Kusairi, S. (2020). Pengembangan Multimedia Interaktif Topik Prinsip Archimedes Untuk Mengoptimalkan Student Centered Learning. Jurnal Inovasi Teknologi Pendidikan, 6(2), 171-182.

Dwiqi, G. C. S., Sudatha, I. G. W., \& Sukmana, A. I. W. I. Y. (2020). Pengembangan Multimedia Pembelajaran Interaktif Mata Pelajaran IPA Untuk Siswa SD Kelas V. Jumal EDUTECH UNDIKSHA, 8(2), 33-48.

Gosztonyi, K. (2016). Mathematical culture and mathematics education in Hungary in the XXth century. In Mathematical cultures (pp. 71-89). Birkhäuser, Cham.

Illahi, T. A. R., Sukartiningsih, W., \& Subroto, W. T. (2018). Pengembangan Multimedia Interaktif Pada Pembelajaran Materi Jenis-Jenis Pekerjaan Untuk Meningkatkan Kemampuan Berpikir Kritis. Jurnal Kajian Pendidikan Dan Hasil Penelitian, 4(3).

Knijnik, G. (2007). Brazilian Peasant Mathematics, School Mathematics and Adult Education. Adults Learning Mathematics, 2(2), 54-62.

Mazana, M. Y., Montero, C. S., \& Casmir, R. O. (2019). Investigating Students' Attitude towards Learning Mathematics. International Electronic Journal of Mathematics Education, 14(1), 207-231.

Mustamin, S. H. (2017). Pembelajaran Matematika Dengan Pendekatan Realistik. Lentera Pendidika, 20(2), 231-239. https://doi.org/10.24252/lp.2017v20n2i8

Nadhilah, S., Purwoko, R. Y., \& Nugraheni, P. (2020). Analisis Kebutuhan Pengembangan E -Modul Berbasis 
Etnomatematika Produk Budaya Jawa Tengah. Jurnal Penelitian Matematika Dan Pendidikan Matematika, 4(2), 112-118.

Nugroho, I. A., \& Surjono, H. D. (2019). Pengembangan Multimedia Pembelajaran Interaktif Berbasis Video Materi Sikap Cinta Tanah Air Dan Peduli Lingkungan. Jurnal Inovasi Teknologi Pendidikan, 6(1), $29-41$.

Nurdyansyah. (2019). Media Pembelajaran Inovatif. UMSIDA Press.

Nusaibah, N., \& Murdiyani, N. M. (2017). Pengembangan Perangkat Pembelajaran Matematika Dengan Pendekatan Pmri (Pendidikan Matematika Realistik Indonesia) Pada Materi Pokok Perbandingan Untuk Siswa Kelas Vii Smp. Seminar Matematika Dan Pendidikan Matematika, 3(1), 475-482.

Sevinc, S., \& Lesh, R. (2018). Training mathematics teachers for realistic math problems: a case of modelingbased teacher education courses. ZDM, 50(1), 301-314.

Wahyugi, R., \& Fatmariza. (2021). Pengembangan Multimedia Interaktif Menggunakan Software Macromedia Flash 8 Sebagai Upaya Meningkatkan Motivasi Belajar Siswa Sekolah Dasar. Jurnal Ilmu Pendidikan, 3(3), 785-793.

Widodo, S. A. (2018). Selection of Learning Media Mathematics for Junior School Students. Turkish Online Journal of Educational Technology-TOJET, 17(1), 154-160. 